74 巻 737 号 (2008-1)

\title{
立ち上がり動作追従型介助座椅子の開発* (作用力の特性)
}

\author{
記 州 智 美*1, 小泉 邦 雄*2, 木下功 $土^{* 3}$

\section{Development of Legless Chair with Seat Motion Which Follows Standing Up Action (Characteristics of Action Force)}

\author{
Tomomi KISHU, Kunio KOIZUMI*4 and Kohji KINOSHITA \\ ${ }^{* 4}$ Graduate School of Science and Engineering for Research, University of Toyama, \\ 3190 Gofuku, Toyama-shi, Toyama, 930-8555 Japan
}

\begin{abstract}
The paper presents characteristics of action and reaction force in the chair drive mechanism. When axis of the rotation link approaches horizontally in the legless chair state, tensile force acting in the drive wire increases rapidly. Therefore, big power actuator is required at early lifting stage. A few solutions were considered to reduce the peak necessary drive force. The first, rigidity of wire is sufficiently increased so that there may be completely no elongation. The second, the peak is canceled by addition of boost effect of gas spring. The third, axis of the rotation link is constrained by landing stopper, before the link is achieved in a horizontal position. The actuator with function of irreversible motion must be used the mechanism, because the pullback force is needed near standing position. The experimental results agree approximately with the theoretical analysis, and then theoretical considerations could be proved for its validity.
\end{abstract}

Key Words: Medical and Welfare Assistance, Mechanism, Optimal Design, Welfare Machine, Legless Chair, Standing Up Support

\section{1. 緒言}

高歯化の急激な進行によって要介護者が急增してい る. それとともに，多くの介護支援機器が工夫開発さ れて来ており，多くは如何に楽に作業ができるかに力 が注がれている. 高齢者は何事にも億劫になりがちで あり, 自立能力が低下して介護が必要となる前に, 日 常生活の行動の中で気軽に身体を動かすことで，無意 識に身体機能の残存能力を維持さらには強化して, QOL (Quality of Life : 生活の質) の低下を抑止するこ とが望ましい. 最も重要な身体機能は自力による立ち 上がりであり，椅子からの立ち上がり動作については 多くの研究がされている ${ }^{(1) 22}$. 本研究で開発した介助座 椅子は, 最も厳しい抗重力動作である床からの立ち上 がりを対象に, 安全に介助するために自然な立ち上が りに追従するように座面が上昇するときに前傾前出す る運動を原理的に 1 つのアチュエータのみで行うこ とが可能な機構(3)によって, ワイヤ長を変えずにスラ

\footnotetext{
* 原稿受付 2007 年 3 月 15 日.

*1 正員, 富山大学大学院理工学研究科( 930-8555 富山市五 福 3190).

*2 正員, 富山大学大学院理工学研究部.

*3 正員, 富山大学工学部.

E-mail : precm@eng.u-toyama.ac.jp
}

イドプーリ位置を移動調節するだけでこの座面動作を 変化させ,個体差および高齢者に著しい身体能力の経 年変化に容易に対応できる特長を有する.この機構の 動作中の機構各部に作用する力を理論的に考究して, ワイヤ張力やアクチュエータ出力の特性を明らかにし て実用設計のための概略見積もりに役立つ近似式を求 めた. アクチュエータの所要駆動力およびワイヤ張力 は，ワイヤ剛性が十二分に高ければ，座面の上昇とと もに単調に減少するが，座椅子状態からの上昇初期に ワイヤの微小な等価的伸びを生ずると，これらにピー クを生ずる.これを抑えるには結果的にプーリ支持軸 受の抵抗卜ルクを抑えるとともにワイヤ岡性を十分高 くする必要があるが, ガススプリングのような回生ア クチユエータをブースタに用いて, 駆動力のピークを 低減する方法が有効であることも示した。

\section{記 号}

長さは座面リンク長 : $l_{1}$, 力は体重 : $w$ を基準に次 の無次元量を定義する. 各リンク長さ: $L_{i}=l_{i} / l_{1}$, 上体 上腿・下腿重量, 各部材自重: $W_{i}=w_{i} / w$, 点 $O$ を原点 とする各座標 : $X_{i}=x_{i} / l_{l}, Y_{i}=y_{i} / l_{1}$, 部材 - 人体への作 用力: $P_{i x}=p_{i x} / w, P_{i j}=p_{i y} / w$, 部材・人体が受ける反力: $R_{i x}=r_{i x} / w, R_{i y}=r_{i j} / w$, 張力 : $\boldsymbol{T}=T / w$, アクチュエー夕 
出力 : $\boldsymbol{F}_{x}=F_{x} / w, \boldsymbol{F}_{y}=F_{y} / w$, 駆動および関節モ一メン 卜 : $\boldsymbol{M}_{o, k, n}=M_{o, k, n}\left(\left(w l_{l}\right)\right.$, ワイヤ岡性 : $K=k /\left(w / l_{1}\right)$

\section{2. 構造と動作原理}

高齢者に多く見受けられる滕関節症や下肢筋力の低 下によって立ち上がりが困難になった場合の自立した 在宅生活を支援するために, 図 1 のように自然な立ち 上がりに追従して座面が動作する座椅子を実現する目 的で，図2のような座面押上げ機構を開発した ${ }^{(3)}$. 座 椅子に近い状態では, 座面を水平に保って上昇し, 椅 子状態からは座面を前傾前出して腰を前に押し出し， 自立を容易にする. 旋回リンク $O A$ の円弧運動で座面 を昇降し,点E-P-O-Cのワイヤで座面を前傾前出する. 点Dにリニアアクチュエータとガススプリング推力を 作用させ, 旋回リンクが回転すると, スライダ $C$ はワ イヤに引つ張られて点 $B$ を押し上げる.

\section{3. 作用力の特性解析}

\section{3 -1 作用力モデル 後述のように機構の動作は} 十分に遅いので, 静力学的考察が可能であり, また, プーリにかかる抵抗トルクが十分小さいので，ワイヤ 張力 $\boldsymbol{T}$ は一定とみなせ, 図3のように, 機構を構成す る各リンク節点の作用・反作用を考えることにする.

作用力は下および左, 反力は上および右方向を正, および微小なワイヤの伸びを無視し, 全て図示した方 向を正と定義する. 上体が主に珼部で座面支持され， 上腿が下腿で支えられて膝が浮き, 大腿部が座面を強 く押していないことと, 立ち上がるまで着座位置がず れないことから,人体 $H Q K N$ を点 $Q$ でピン接合する.

3.2 作用力解析 最終的にアクチュエータの所 要出力を求めるために, 以下の手順をとる.

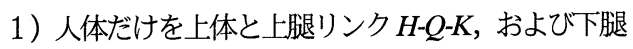
リンク $K-N$ の 2 リンクに分け, 機構の $A-B, B-C, D-F$, $D-O-A$ と合わせた 6 リンクについて,水平·鉛直方向の カとモーメントの 18 のつりい式を導く.

2) 点 $A, B, D, K, Q$ の作用反作用の 18 関係式中の 次の 18 の末知量 $\left(R_{a x}, R_{a y}, R_{b x}, R_{b y}, R_{c y}, R_{d x}, R_{d y}\right.$, $\left.R_{k x}, R_{k y}, R_{n x}, R_{n y}, R_{q x}, R_{q y}, R_{a x}, R_{o y}, T, F_{x}, F_{y}\right)$ 以 外を消去して整理する. その内, 機構の関係式から分 離した人体リンクだけの 6 元連立方程式から $R_{q x}, R_{q y}$ 以外を消去すると次式が得られ，人体と機構を結合す る力成分 $R_{q x}, R_{q y}$ が定まる.

$\left[\begin{array}{ll}L_{k 1} \cdot \sin \theta_{k} & -L_{k 1} \cdot \cos \theta_{k} \\ L_{k 2} \cdot \sin \theta_{n} & -L_{k 2} \cdot \cos \theta_{n}\end{array}\right]\left[\begin{array}{l}R_{q x} \\ R_{q y}\end{array}\right]$
人体の残りの未知量 $R_{k x}, R_{k y}, R_{n x}, R_{n y}$ は, 人体の力の 4 つのつりあい式に式(1)の解を代入して定まる.

$A B$ リンクの点 $A$ まわりのモーメントつりあい式で, 点 $B$ の作用力 $R_{b x}$ と $R_{b y}$ を力のつりあいと作用反作用の 関係式から $R_{c y}$ と $\boldsymbol{T}$ を用いて表した式,および $B C$ リン クの点 $B$ まわりのモーメントつりあい式を連立させて, $R_{c y}, T$ 以外を消去すると, 次式となる.

$\left[\begin{array}{ll}L_{1} \cos \theta_{2} & L_{1} \sin \theta_{2} \\ L_{2} \cos \theta_{3} & L_{2} \sin \theta_{3}\end{array}\right] \cdot\left[\begin{array}{c}R_{c y} \\ T\end{array}\right]$

$=\left[\begin{array}{c}W_{a b} \frac{L_{I}}{2} \cos \theta_{2}+W_{b c} L_{1} \cos \theta_{2}-R_{q y}\left(L_{I}-L_{q}\right) \cos \theta_{2}+R_{q x}\left(L_{1}-L_{q}\right) \sin \theta_{2} \\ W_{b c} L_{2} / 2 \cdot \cos \theta_{3}\end{array}\right]$

力のつりあいと作用反作用の関係式からD-O-A リンク

の点 $O$ 周りのモ一メントの式を $R_{c y}, T, R_{q x}$ および

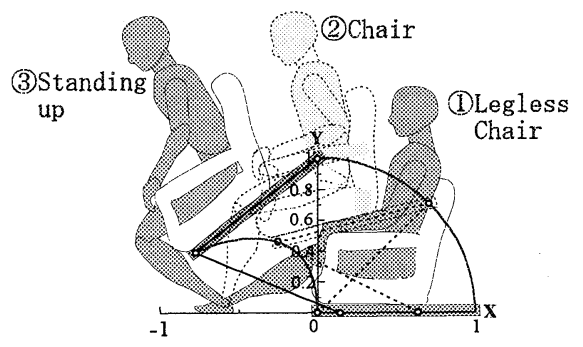

Fig. 1 Assistance of standing up action in legless chair

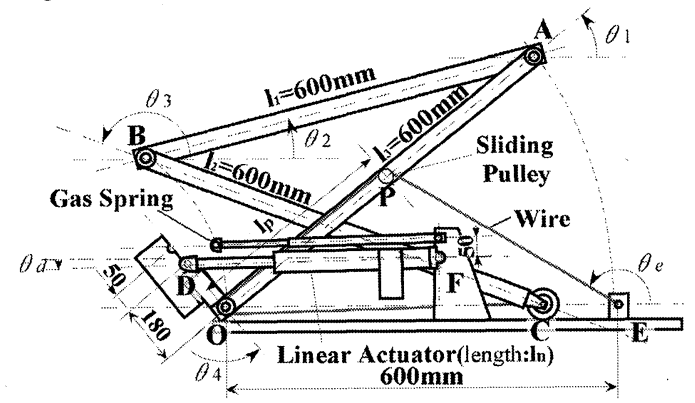

Fig.2 Standing support mechanism for trial

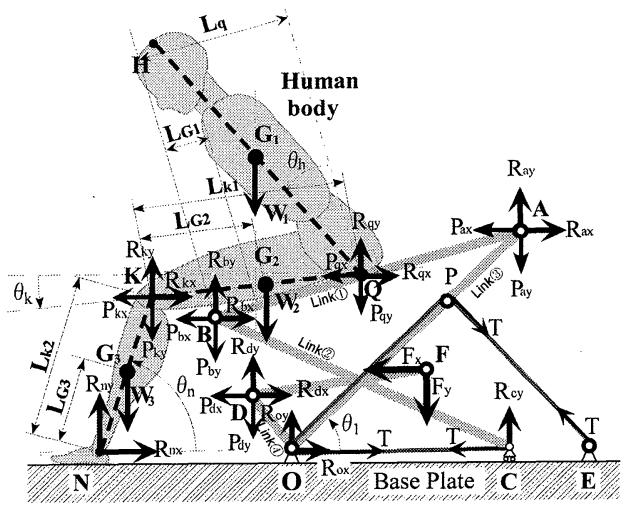

Fig.3 Acting distribution of forces 
$R_{\mathscr{y}}$ で表した式, および $D-F$ リンクの点 $D$ 周りのモー メントの式を $\boldsymbol{F}_{x}, \boldsymbol{F}_{y}$ で整理すると, 次式が得られる。

$\left[\begin{array}{cc}L_{4} \cos \theta_{1} & L_{4} \sin \theta_{1} \\ L_{n} \sin \theta_{d} & -L_{n} \cos \theta_{d}\end{array}\right] \cdot\left[\begin{array}{l}\boldsymbol{F}_{x} \\ \boldsymbol{F}_{y}\end{array}\right]$

$=\left[\begin{array}{c}W_{o a} L_{3} / 2 \cdot \cos \theta_{1}-W_{o d} L_{4} / 2 \cdot \sin \theta_{1}+\left(W_{a b}+W_{b c}-R_{c y}-R_{q y}\right) L_{3} \cos \theta_{1} \\ -\left(\boldsymbol{T}-R_{q x}\right) L_{3} \sin \theta_{1}+\boldsymbol{Z}_{p} \sin \left(\theta_{e}-\theta_{1}\right) \\ W_{d f} L_{n} / 2 \cdot \cos \theta_{d}\end{array}\right]$

アクチュエータの駆動モーメントは, 式(3)を解いた駆 動力成分 $\boldsymbol{F}_{x}, \boldsymbol{F}_{y}$ を用いると，次式で表される.

$\boldsymbol{M}_{o}=L_{4}\left\{\boldsymbol{F}_{x} \sin \left(\theta_{1}+\theta_{4}\right)-\boldsymbol{F}_{y} \cos \left(\theta_{1}+\theta_{4}\right)\right\}$

各部にかかる力は式(1)から(3)の解を消去前の元の 式に戻して求められるが, その結果, スライダ部の点 $C$ に作用する垂直反力 $R_{c y}$ は常に正方向となって,スラ イダは常に垂直下方へ押し付けられるので, 浮き上が りを防ぐガイドは不要であることがわかった。

\section{4. 作用力特性}

4·1 作用力 図3 の機構および人体のモデル(4)(5) のパラメー夕の標準値を表 1 に示す. 着座位置 $Q$ は座 面前端 $B$ から座面全長 $A B$ の $50 \%\left(L_{q}=0.5\right)$, 足は点 $O$ から前方へ座面全長の $60 \%\left(X_{n}=-0.6\right)$ の位置に置 き, 上半身は座面と直角 $\left(\theta_{h}=0^{\circ}\right)$ を保つ. 接続リン ク $O D$ は旋回リンク $O A$ の所要稼働範囲を確保するた めに座面リンク $A B$ の $30 \%\left(L_{4}=0.3\right)$ である. 部材重 量は体重に比べて微小なために作用力特性の本質には 影響しないので，本論文中では全て 0 とした。

$4 \cdot 2$ 駆動モーメント 四4に旋回リンク $O A$ の回 転角 $\theta_{1}$ に対して,スライドプーリ取り付け位置 $L_{p}$ をパ ラメータとした点 $O$ に作用させる所要駆動モーメント の変化を示す. 破線 $\left(L_{p}=0.67\right)$ よりも上は後出の図 7 , 8 も同様に, 上昇途中で座面が一時後傾する条件であ る.したがってスライドプーリの取り付け位置は, 自 然な立ち上がり動作の睯部の運動に座面が追従するこ とに加えて, 椅子状態付近での座面の傾斜が小さくな る $L_{p}=0.67$ が適当であると思われる ${ }^{(\oplus)}$ 点 $P$ をこれ以 上高くして点 $A$ へ近づけ, $L_{p}$ を大きくすると, 特に $\theta_{1}$ が $0^{\circ}$ 近くに下がっているときにアクチユエータの駆 動モ一メントが急増する不都合が出るが, これは, 点 $B$ を急速に押し上げる性質上点 $C$ を強く引かねばなら ないためのワイヤ張力の急増によることと, 点 $P$ にか かる張力による点 $O$ 周りのモーメントの腕が長くなる ことも加わる. $\theta_{1}$ が大きくなると駆動モ一メントが負 になるが, 座面が前に出て全重心が点 $O$ よりも前に出 るために, アクチュエータのロッドを引き出す力が作
用するので，引き戻す方向の駆動モーメントでつりあ うことを示す. 実機はウォ一ム減速機構ゆえ,逆転では ロックがかかり, 所要駆動モーメントが 0 になる.

$4 \cdot 3$ ワイヤ張力 図 5 はワイヤ張力を示し, $\theta_{1}$ が 0 に近づいて座椅子状態になるとスライダリンク $B C$ が水平に近づくので，点 $C$ を引いて点 $B$ を押し上 げる力よりも, リンク $B C$ の軸圧縮力となる張力成分 が大きくなり, 点 $P$ の位置に関係なく急增する.この ため点 $O$ や点 $P$ れを避けるためにも後述の回避策を取る必要がある.

\section{$4 \cdot 4$ 不感帯の影響 ワイヤ岡性が十分高く, 伸} びないとすると, $\theta_{1} \rightarrow 0$ でワイヤ張力が急増する不都 合の外に, 実験では, $\theta_{1}$ が小さいときに所要駆動力に ピークを生じて前述の理論解析の傾向とは異なった. 初期の座椅子状態から駆動したとき, 図 10 の実験值の ように，リニアアクチュエータを駆動してロッドが伸 びても座面を保持する剛性が無限大にならず，リンク 組立結合部や各部材の弾性による微小変形のために旋 回リンク $O A$ が動かずに駆動モ一メントが増えていく 不感帯が出た. 次に旋回リンク $O A$ が回転しても, ワ イヤの曲がり癖と両端玉掛部のワイヤの曲がりが直さ れるために全長が長くなり, あたかもワイヤ自体の伸 びと同じ効果を示し, 点 $B$ が着床のまま点 $O$ の位置か ら動かず,モ一メントは式(7)で増大して座面後部だけ が持上げられる不感帯が出た. ワイヤの伸びとともに

Table 1 Standard values of human and link mechanism

\begin{tabular}{|c|c|c|c|c|}
\hline & \multirow[t]{2}{*}{ Link } & $L_{1,2,3}=1$ & $\angle D O A$ & $\theta_{4}=90^{\circ}$ \\
\hline \multirow[t]{2}{*}{ है } & & $L_{4}=0.3$ & $\angle H O K$ & $\theta_{h}=0^{\circ}$ \\
\hline & Cnemis & $L_{k l}=0.60$ & Point E & $X_{e}=1.0, Y_{e}=0$ \\
\hline & Femur & $L_{k 2}=0.60$ & Point $F$ & $X_{f}=0.6, Y_{f}=0.3$ \\
\hline \multirow{4}{*}{ 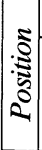 } & Seating & $L_{q}=0.5$ & Point $N$ & $X_{n}=-0.6 Y_{n}=0$ \\
\hline & \multirow{3}{*}{$\begin{array}{l}\text { Center of } \\
\text { gravity in } \\
\text { body parts }\end{array}$} & $L_{G 1}=0.54$ & \multirow{3}{*}{$\begin{array}{l}\text { Weight of } \\
\text { body } \\
\text { parts }\end{array}$} & $W_{1}=0.65$ \\
\hline & & $L_{G 2}=0.33$ & & $W_{2}=0.22$ \\
\hline & & $L_{G 3}=0.34$ & & $W_{3}=0.13$ \\
\hline \multicolumn{2}{|c|}{ Joint moment } & $\boldsymbol{M}_{k, n}=0$ & Body weight & $w=568 \mathrm{~N}$ \\
\hline
\end{tabular}

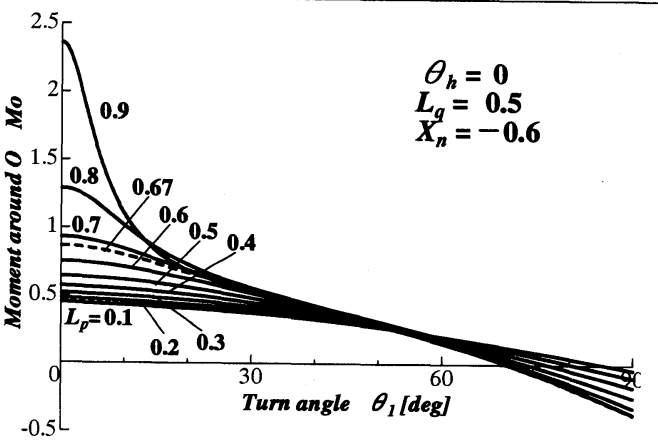

Fig.4 Change of drive moment around $\mathrm{O}$ 
張力が増して $\theta_{l}=7^{\circ}$ で点 $B$ が浮き上がった.この ように駆動の初期に，2つの不感帯が現れた。

座面リンク $A B$ の点 $B$ 周りのモ一メントを求めると,

$L_{q}\left(R_{q x} \sin \theta_{2}-R_{q y} \cos \theta_{2}\right)+L_{1}\left(R_{a x} \sin \theta_{2}-R_{a y} \cos \theta_{2}\right)=0$ (5)

$D-O-A$ リンクの点 $O$ 周り, および $D-F$ リンクの点 $D$ 周りのモーメントのつりあい式を整理すると，

$$
\begin{aligned}
& {\left[\begin{array}{cc}
L_{4} \cos \theta_{1} & L_{4} \sin \theta_{1} \\
L_{n} \sin \theta_{d} & -L_{n} \cos \theta_{d}
\end{array}\right] \cdot\left[\begin{array}{l}
\boldsymbol{F}_{x} \\
\boldsymbol{F}_{y}
\end{array}\right]} \\
& =\left[\begin{array}{c}
-L_{1}\left(R_{a x} \sin \theta_{1}-R_{a y} \cos \theta_{1}\right)+\boldsymbol{T} L_{p} \sin \left(\theta_{e}-\theta_{1}\right) \\
0
\end{array}\right]
\end{aligned}
$$

点 $B$ が動かないときの $\theta_{2}=\theta_{1}$ として変形した式(5)を式 (の)に代入して $\boldsymbol{F}_{x}, \boldsymbol{F}_{y}$ を求め, これを式(4)に代入する と,アクチュエータの所要駆動モーメントは

$$
\boldsymbol{M}_{o}=\left(R_{q x} \sin \theta_{1}-R_{q y} \cos \theta_{1}\right) \cdot L_{q}+\boldsymbol{T} \cdot L_{p} \cdot \sin \left(\theta_{e}-\theta_{1}\right)
$$

となり, 図6のようにワイヤ剛性が高いほど急に 立ち上がる. その後はワイヤ全長が $S$ から $S+\Delta S$ に 換わり，モ一メントは式(4)で単調减少する. したがっ て, 点 $B$ が浮き上がる限界の $\theta_{1}=\theta_{I p}$ でピークとなる. 第2の不感帯において，ワイヤが伸びるとき，次式

$$
\boldsymbol{T}=K \cdot \Delta S
$$

のように初期張力を 0 とし, 線形項が卓越した張力変 化とみなすと，図 5 に示したようにワイヤ剛性 $K$ が 高いほど $\theta_{1}=0$ から急に立ち上がる. ワイヤの初期伸 延領域では,張力は式(8)より $\theta_{1}$ に対して単調増加し, $\theta_{1}=\theta_{I p}$ における張力は, 前述のワイヤ全長 $S+\Delta S$ を式 (2)に用いて求められ, $\theta_{1}$ に対して単調减少する. した がって, このときに張力 $\boldsymbol{T}_{p}$ もピーク值を示し, 駆動モ 一メントがピークとなるときと一致する.

このように， $\theta_{1}$ が小さいときにワイヤ張力およひ駆 動モ一メントがピークで増大する不都合の回避策は，

1) 吊り下げ支持構造の座面とし, 旋回リンクおよびス ライダリンクが水平に近づく前に座面を着床させる.

2) ワイヤ岡性を十分に高くして伸びを無くす.したが って,高剛性ベルトやチェーンなども検討を要する.

3) ピーク付近でアクチュエー夕出力を支援する.

が考えられる.

式(7)を $\theta_{1}=0$ で展開すると，表 1 の条件では，

$$
\boldsymbol{M}_{\boldsymbol{o}} \approx 0.43-0.06 \theta_{1}-0.12 \theta_{1}^{2}+\frac{K}{2} \cdot\left(\frac{L_{p}}{1-L_{p}}\right)^{2} \theta_{1}^{3}
$$

となって， $\theta_{1}$ の 3 乗で立ち上がり変化するとみなせ， 立ち上がりはワイヤ岡性 $K$ の 1 乗で効いて急になる. $L_{p}$ については, 前述の 0.67 程度をとると, $K$ の影響に 比べて非常に小さいので，特に考慮する必要はない。
このときのワイヤの伸びの展開式より, ワイヤ張力は

$$
\boldsymbol{T} \approx K \cdot \frac{L_{p}}{2\left(1-L_{p}\right)} \theta_{1}^{2}
$$

となって, $\theta_{1}$ の 2 乗で立ち上がるとみなせ $L_{p}$ の影響 は駆動モーメントよりもさらに小さい。

旋回リンクを駆動して $\theta_{1}$ が増すとワイヤ張力が増 大し, 点 $A$ 周りのモ一メントがつりあう次式の解 $\theta_{1}=\theta_{I p}$ で駆動モ一メントとワイヤ張力がピークとなる. $\left(1-L_{q}\right) \cdot\left(R_{q x} \sin \theta_{1 p}-R_{q y} \cos \theta_{l p}\right)-\boldsymbol{T} \cdot \sin \theta_{1 p}=0$

$K$ の值が大きいために $\theta_{1 p}$ はかなり小さくなるので， 式(11)を $\theta_{1}=0$ の近傍で展開した表 1 の条件における

$0.43-0.06 \theta_{1 p}-0.12 \theta_{I_{p}}{ }^{2}-K \cdot \frac{L_{p}}{2\left(1-L_{p}\right)} \theta_{1 p}{ }^{3} \approx 0$

の解 $\theta_{1 p}$ を式(9)と(10)に用いて，ピーク值は

$\boldsymbol{T}_{p} \approx K \frac{L_{p}}{2\left(1-L_{p}\right)} \theta_{1 p}{ }^{2}, \boldsymbol{M}_{o p} \approx \frac{\boldsymbol{T}_{p}}{1-L_{p}} \theta_{1 p}$

となり，いずれもワイヤ岡性 $K$ の 1 乗に比例して増大 するとみなせる. 図7に示すように所要駆動モ一メン トである $\boldsymbol{M}_{o p}$ は $K$ がある程度以上大きいとほぼ一定で ある. 式から一見 $K$ の低い方が $\boldsymbol{M}_{\boldsymbol{~}}$ を抑えられるよう に思えるが, 図 8 に示すように, $K$ が小さくなると図 5 や 6 のごとく $\theta_{1 p}$ が大きくなって, 座面が十分

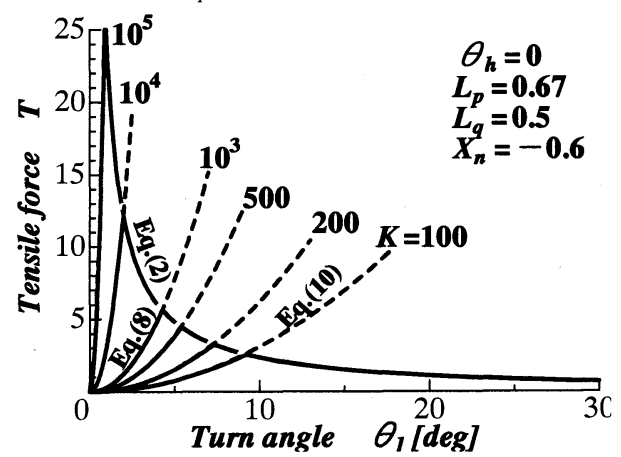

Fig.5 Change of wire tension with turn angle

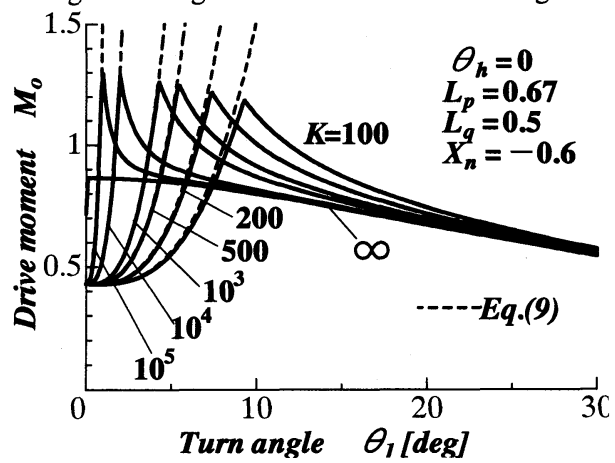

Fig.6 Appearance and change of peak drive moment for wire elongation 
に下がる前にピークが出てしまい，前述の回避策 1)を 取っても $\boldsymbol{M}_{o p}$ を小さくできない可能性がある上，図 6 のように駆動モーメントが, $K=\infty$ の曲線を上回る範囲 も大きくなる. このため, 回避策3)を取っても後述す る図 12 のように補助推力がなくなった瞬間の駆動モ 一メントを抑えられないこともある. また，点 $\mathrm{B}$ の上 昇開始が遅れるのに伴って，座面が十分に上昇しない 不都合も生じる. 逆に $K$ を大きくとるほど回避策 2) に近づき $\theta_{l p} \rightarrow 0$ になるので, 回避策 1)を取りやすく, かつ，回避策3)を取らねばならない範囲も狭くなる.

\section{5. 実験}

$5 \cdot 1$ 試作実験装置 図 2 で示した座面両側にア ルミニウム合金押出構造材のリンク機構を配置し，外 側に可変速電動リニアアクチュエータ(侏)日本工无沙ク, $\mathrm{DC} 24 \mathrm{~V}$, 最大推力 $1 \mathrm{kN}$, 動作範囲 $200 \mathrm{~mm}$ ）を取り付 けた. 表 1 の標準身体寸法を考虑して, $A B \cdot B C \cdot A O$ のリンク長を $600 \mathrm{~mm}$ とし, アクチュエータの動作行 程から $D O$ を $180 \mathrm{~mm}$ とした. 点 $O$ と $P$ のプーリと点 $C$ の $\phi 40 \mathrm{~mm}$ プラスチックローラは玉軸受で支持して 摩擦抵抗卜ルクを十分低減した. 点Aの接線速度を高 齢者が危険を感じない程度の $2 \mathrm{~cm} / \mathrm{s}($ 角速度 $2 \mathrm{deg} / \mathrm{s})$ に設 定し，座面を駆動した。このときプーリ回転速度は 1.4rpm で十分に遅く, 静的とみなせる.

5.2 実験方法 四9のように, 試作機の点 $B, A$, $O$ および被験者（男，身長 $1.61 \mathrm{~m}$ ，体重 $568 \mathrm{~N}$ ）の肩， 大転子, 膝およびくるぶしに $\varnothing 20 \mathrm{~mm}$ 位置検出用反射 球を貼り付けて，ビデオカメラの画像とロードセルで 検出した作用力をパソコンに取り込んでデー夕解析し た. 足の位置は $X_{n}=-0.592(355 \mathrm{~mm})$ に固定した.

$5 \cdot 3$ 実験結果 図10にヒトを載せたときを示す. ワイヤ岡性の基準量である被験者の体重と座面リンク 長の比の值は $947 \mathrm{~N} / \mathrm{m}$ であり, 実験結果の $\theta_{1 p}=7^{\circ}$ を式 (11)に用いて $K=215$ となり, ワイヤ等価剛性は $201 \mathrm{kN} / \mathrm{m}$ と推定される. このとき駆動力のピーク值は $418 \mathrm{Nm}$ であり，対応する理論值は $416 \mathrm{Nm}$ となる. 本 装置では $\theta_{1}=20^{\circ}$ までは大きな駆動力を必要とする.

\section{6. パワーブーストによる駆動力低减}

$6 \cdot 1$ ガススプリングの併用 本実験装置のワイ ヤの初期伸びのように, $\theta_{1}=0$ の座椅子状態からの初期 動作段皆で座面動作に不感带を生ずる機構の場合には, 図 10 のように所要駆動力の急激な立ち上がりでピー クを示す. ピーク付近を除けばアクチュエータの所要 能力を低減できるが，一時的とは言え，このピークレ ベルを出力可能な大容量アクチユエータが必要になる.
これを回避するために，ピーク付近の高負荷をブース 夕で低减することを試みた。

大きな駆動力を要するのは，立ち上がり駆動初期だ けで，着座の場合にはアクチュエー夕は位置エネルギ

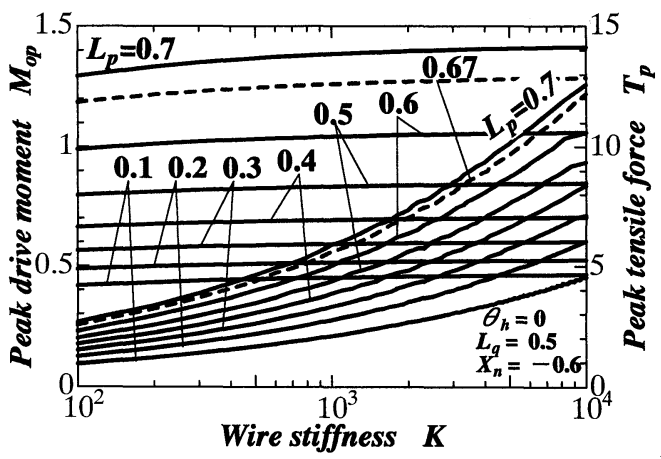

Fig.7 $\begin{aligned} & \text { Prediction of peak drive moment } \\ & \text { and corresponding wire tensile force }\end{aligned}$

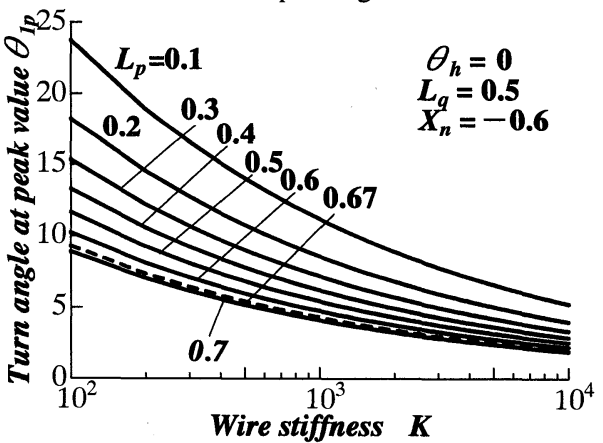

Fig.8 Prediction of turn angle at peak value

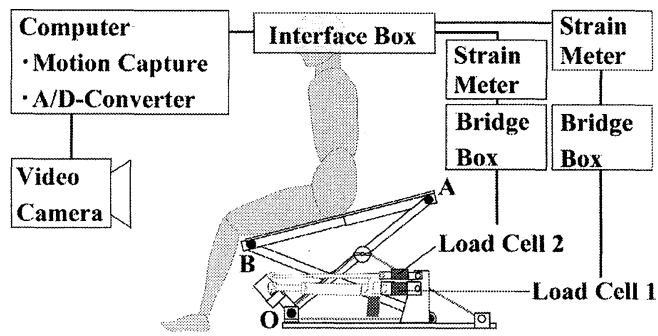

Fig.9 Constitution of an experimental device

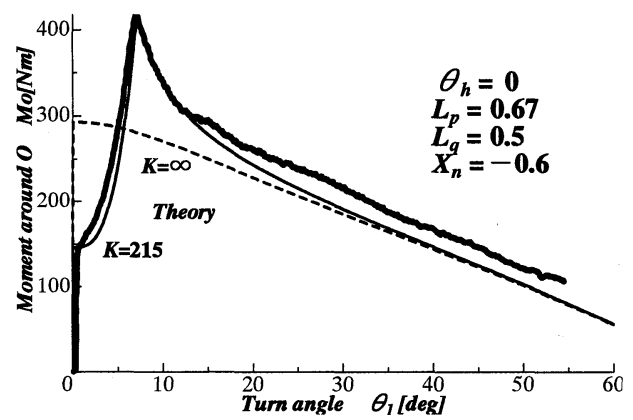

Fig.10 Change of drive moment (Experiment) 
を放出するブレ一キの作用をすればよいので，このと きにエネルギを回収して次の立ち上がり動作時に利用 することを考えて, 電源が不要な回生アクチュエータ であるガススプリングを用い, リニアアクチュエータ の発生力を効果的に低減するためには, 発生力方向を 合わせる必要があるので,図 2 および図 11 のようにリ ニアアクチュエータとガススプリングのロッド軸を平 行に合わせた. 横置き可能なフリーピストン式ガスス プリング（侏トキコ, T284A : 出力 308〜389N, 動作 範囲 100mm, T285A: 出力 411 485N, 動作範囲 60mm) の2種を用いた. 前者は発生力が小さいが作動範囲が 広く, 後者は範囲は狭いが大きな駆動力が得られる.

6.2 ブースト実験 図11のようにガススプリン グとアクチュエータ端部に歪ゲージ式ロードセルを挿 入して検出した発生力を図 12 に示す.駆動初期から駆 動力がステップ上に立ち上がっているときまでブース 夕を働かせるように設定してあり,それ以上では図 11 左上図のように溝から離れる.ブースタが無いときの アクチユエータ最大出力 $2.5 \mathrm{kN}\left(\theta_{1}=7^{\circ}\right)$ に対して, T284A では $26 \%$ 減の最大出力 $1.86 \mathrm{kN}\left(\theta_{l}=7^{\circ}\right), \mathrm{T} 285 \mathrm{~A}$ では $36 \%$ 減の最大出力 $1.59 \mathrm{kN}\left(\theta_{1}=7^{\circ}\right)$ に抑えられた。 したがって, ブースタを用いない場合には, 最大出力 $1.25 \mathrm{kN}$ リニアアクチュエータを 2 本必要としたが, T285A のブースタを付加すると, 出力 $800 \mathrm{~N}$ が 2 本で よく, 所要出力を大幅に低減することができた.

\section{7. 結 論}

立ち上がり動作追従型介助座椅子の動作時に作用す る力について考究し, 以下のような結果を得た.

1)ワイヤの伸びが無ければ, 張力は旋回リンクが水平 に近づくほど単調に増大する。

2) スライダには常に下向きの力が作用するので, 浮き 上がり防止ガイドは不要である.

3) 立ち上がり状態に近づくと引き戻し駆動力を要す るので,不可逆機構付アクチユエータが必要である.

4) ワイヤを用いて弾性を与えると, 座面にクッション 性を与え，座り心地を向上できる.

5) ワイヤの等価的弾性による伸びで所要駆動力およ びワイヤ張力がピーク值を示し，その值はワイヤ剛 性の 1 乗に比例するとみなせる.

6) ワイヤ張力と所要駆動力のピーク值を抑えるには, プーリの抵抗トルクを小さくする必要がある.

7) 同時に, 十分高いワイヤ岡性を要するので, 高剛性 ベルトやチェーンなどの使用も考える必要がある.

8) エネルギ回生と機構簡単化のためにガススプリン

グをブースタに用いて, 座椅子状態からの初期上昇
時に所要駆動力のピークを効果的に低减できた.

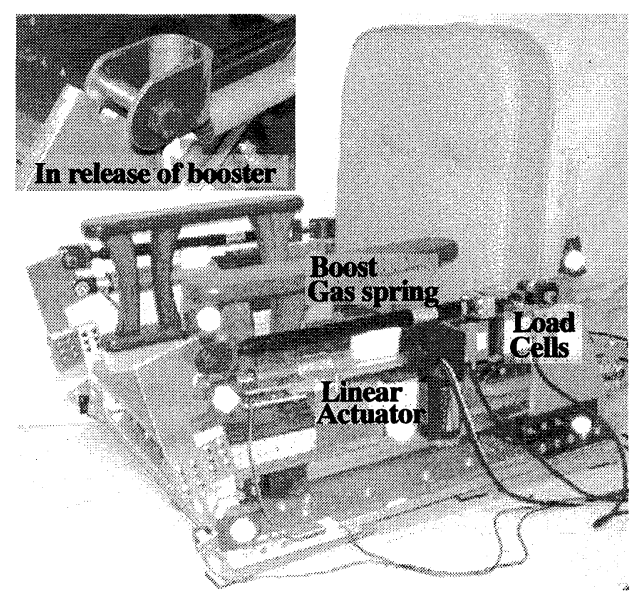

Fig.11 Prototype instrument for experiment

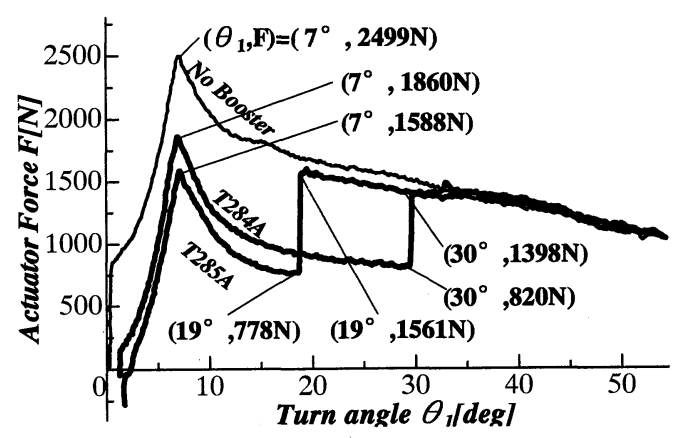

Fig.12 Boost effect to actuator output (Experiment)

\section{文献}

(1) Okada, E. et al., Analysis of Standing Up Motion Assistance on Nursing, Proceedings of Welfare Engineering Symposium 2005, No.05-44 (2005-8), pp. 143-146.

(2) Chugo, D. et al., Force Assistance System for Standing-Up Motion $1^{\text {st }}$ Report:Required Assistance Power for Standing-Up, Proceedings of Welfare Engineering Symposium 2005, No.05-44 (2005-8), pp. 257-260.

(3) Koizumi, K. et al., Standing-Up Assistance Instrument, Japanese Patent , 3660863 (2005-6)

(4) Matsui, H., Sports and Center of Gravity of Human Body(Study on Center of Gravity in Several Posture), (1958), pp. 20, Sports Science. (in Japanese)

(5) Japanese Industrial Standards Center, National Institute of Bioscience and Human-Technology Data Base on Measure of Human Body, (2000)

(6) Mori, M. et al., Fundamental action of assisted standing legless chair lifted up with rolled ball screw, Proceedings of the $39^{\text {th }}$ annual conference of JSME Hokuriku Shin-etsu branch, No.027-1 (2002-3), pp. 201-202. 